\title{
What happens to post-burn surgical rehabilitation in the Ural Federal District? Ways to improve health care
}

\author{
M.Yu. Korostelev ${ }^{1}$, N.G. Shikhaleva ${ }^{1}$, A.V. Gubin ${ }^{2}$, S.O. Ryabykh ${ }^{1}$, O.B. Borzunova ${ }^{1}$ \\ ${ }^{1}$ Ilizarov National Medical Research Centre for Traumatology and Orthopedics, Kurgan, Russian Federation \\ ${ }^{2}$ National Medical Research Center of Traumatology and Orthopedics n.a. N.N. Priorov, Moscow, Russian Federation
}

\begin{abstract}
IIntroduction Eleven million burn injuries have been recorded in the world annually, and 180 thousand of them result in death. Burns are the fourth leading cause of trauma. Mortality in adult patients with burns in the Russian Federation is $4.8 \%$ and $5.3 \%$ in the Ural Federal District. Materials and methods A retrospective analysis of statistical data on the provision of specialized inpatient medical care to patients with thermal trauma in the regions of the Ural Federal District for five years has been undertaken. Results In most regions of the Ural Federal District, there are no transfer protocols for patients with burn injuries. The load on the existing capacity of hospital beds in the regions is uneven. Most of the thermal trauma patients in specialized departments are treated conservatively. Not a single "burns" department of the Ural Federal District has a certified plastic surgeon. Conclusion The following organizational measures are a need: introduction of a unified approach to statistical reports, deployment of surgical beds at departments for burn injury management to provide specialized medical care to patients with various wound defects, referral transfer of patients with the consequences of thermal injury to a specialized federal institution and creation of a unified register of burn patients.

Keywords: combustiology, burn, plastic surgery, thermal injury, wound defects
\end{abstract}

\section{INTRODUCTION}

Burn injuries have been underestimated. However, these injuries lead to serious consequences and death. Burn injuries, especially severe ones, are accompanied by immune and inflammatory reactions, metabolic changes and distributive shock, which are difficult to cope with and which may result in multiple organ failure [1].

According to WHO estimates, 11 million burn injuries of all types have been registered annually in the world, 180 thousand (1.64 \%) of them end in death [2]. Burns are the fourth leading cause of injury [3].

In 2018, 49,262 cases of burns and 3,441 cases of frostbite were registered in the Russian Federation. They account for 1.9 and $0.1 \%$ of all injuries and poisoning cases, respectively [4]. In the structure of hospitalized trauma cases in the Russian Federation in 2018, thermal and chemical burns make $2.8 \%$ among adult and $6.1 \%$ among pediatric patients. Mortality rate was $4.8 \%$ in adult patients with burn injuries in the Russian Federation and 5.3 \%in the Ural Federal District. Also in the Ural Federal District, the highest mortality rate in the Russian Federation was recorded among patients with burn injuries older than working age (11.2 \%). Mortality in children with burn injuries in the Russian Federation was $0.26 \%$ while in the Ural Federal District it was $0.28 \%$.

Purpose of the study was to identify problems and search for the ways to improve the provision of medical care to patients in the field of "burns management" in the regions of the Ural Federal District.

\section{MATERIAL AND METHODS}

The study is a retrospective analysis of statistical indicators in the provision of specialized inpatient medical care to patients with thermal trauma in the regions of the Ural Federal District rendered in 20142018. The data of statistical reports, questionnaire surveys of burn centres (departments) and Ministries (Departments) of the health care system of the Ural
Federal District were analysed. Exception was the Yamalo-Nenets Autonomous Okrug (YaNAO), where there is no separate burns department but there are specialized beds for such trauma in surgical units. The questionnaires included indicators of inpatient performance in providing medical care to patients over a five-year period.

\section{RESULTS AND DISCUSSION}

In the analyzed period, 32,761 patients with burn injuries were treated at the hospitals of the Ural Federal District, including 19,546 adults (59.7\%) and 13,215 children (40.3 \%). The number of pediatric patients discharged decreased by 33 \% over five years. The reduction in the number of discharged adult patients began in 2016 and amounted to $16 \%$ in three years (Fig. 1). 


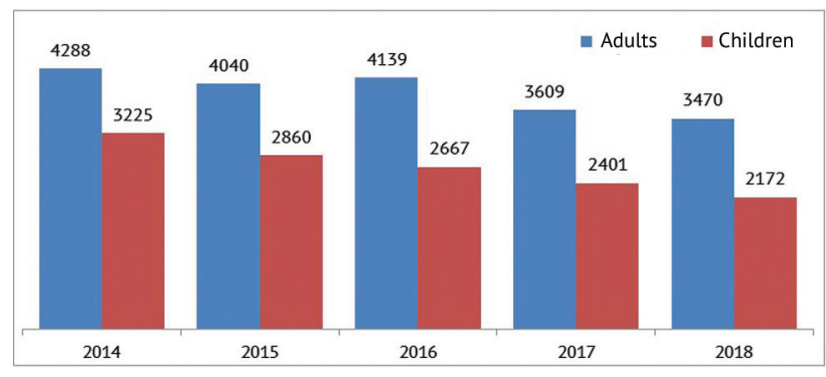

Fig. 1 Dynamics of the number of patients with burn injury discharged from hospitals of the Ural Federal District

A decrease in the number of patients treated in 2018 compared to 2014 (Fig. 2) was noted in all regions, with the exception of adult patients in the Sverdlovsk region, where the number of discharged patients increased by 36 people $(3 \%)$. The largest twofold decrease in the number of injured, detected in the Tyumen region, may have been due to the changes in statistical records, which is also confirmed by the incidence of burn injury in the Tyumen region in 2014 (Table 1).

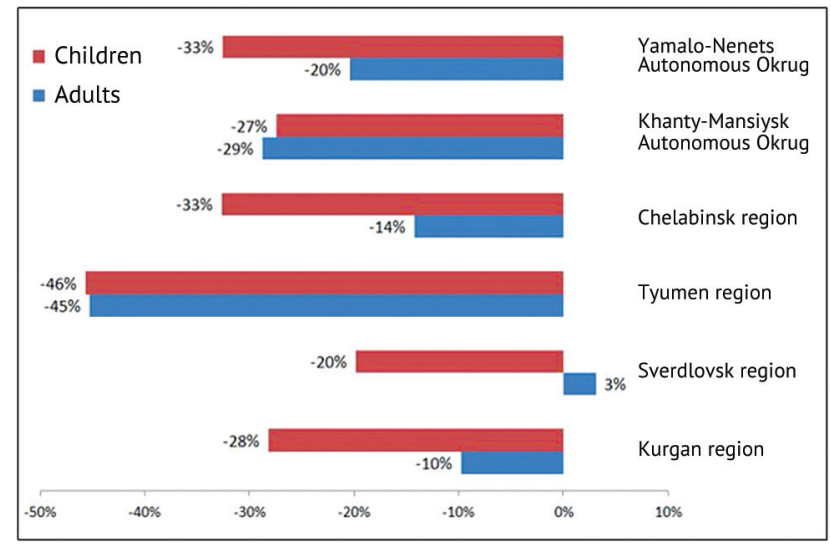

Fig. 2 Relative indicators of the decrease in the number of discharged patients in 2018 to 2014

Table 1

Incidence index for burn injuries treated in inpatient settings in the Ural Federal District

\begin{tabular}{|l|c|c|c|c|c|}
\hline \multirow{2}{*}{\multicolumn{1}{|c|}{ Region }} & \multicolumn{5}{|c|}{ Incidence index (per 1,000) } \\
\cline { 2 - 7 } & 2014 & 2015 & 2016 & 2017 & 2018 \\
\hline Kurgan region & 0.73 & 0.66 & 0.68 & 0.61 & 0.60 \\
\hline Sverdlovsk region & 0.49 & 0.50 & 0.55 & 0.47 & 0.46 \\
\hline Tyumen region & 1.12 & 0.91 & 0.76 & 0.63 & 0.61 \\
\hline Chelabinsk region & 0.47 & 0.47 & 0.45 & 0.42 & 0.37 \\
\hline $\begin{array}{l}\text { Khanty-Mansiysk } \\
\text { Autonomous } \\
\text { Okrug - Ugra }\end{array}$ & 0.61 & 0.52 & 0.50 & 0.48 & 0.44 \\
\hline $\begin{array}{l}\text { Yamalo-Nenets } \\
\text { Autonomous } \\
\text { Okrug }\end{array}$ & 0.58 & 0.56 & 0.53 & 0.46 & 0.43 \\
\hline
\end{tabular}

The incidence index for burn injuries in the Ural Federal District in 2018 has decreased compared to 2014 from 0.60 to 0.46 per one thousand of the population, decreasing evenly in all regions. The highest rates of burn injury incidence over five years have been recorded in the Kurgan and Tyumen regions, the lowest in the Chelyabinsk region (Table 1).
There are five burns departments and one burns centre (Chelyabinsk) in the Ural Federal District for specialized inpatient treatment of thermal trauma, in which 196 specialized beds have been deployed. The number of beds in 2018 decreased in all regions, totally in the district by 43 beds (18\%). Nevertheless, the rate of provision with beds for thermal trauma in three regions of the District significantly exceeds the rate in the RF (0.18 per 10,000 population) (Fig. 3).

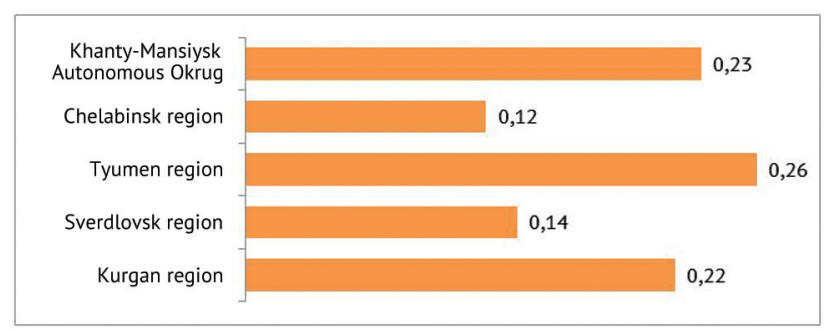

Fig. 3 Indices of the provision with beds for thermal trauma patients per 10,000 of population in the regions of the Ural Federal District in 2018

According to the results of the surveys, it was revealed that only $79.74 \%$ of the injured were treated in specialized beds; the rest of the patients received treatment being admitted to regular surgical units. This testifies to the absence of a clear referral system in the field of burns management. There is an order for a protocol of referral in the Chelyabinsk region.

Attention is drawn to the lack of a unified approach in statistical reporting in the regions. Some departments make calculation according to on the area of burns, others to the depth of tissue damage. Thus, it is impossible to compare the qualitative and quantitative indicators of thermal injuries. To unify the data, it should be recommended to the heads (heads) of burns departments and centers to use the reporting statistical formula of the chief specialist in thermal trauma of the region, developed under the guidance of Professor A.A. Alekseev and approved by the All-Russian public organization of thermal trauma doctors "World without burns" (http://combustiolog.ru). It should be noted that this formula was developed only for burns departments and centers and does not include data for the analysis of burn injuries from regular units in the whole region.

The data obtained in the analysis of the surgical work of the burns departments indicate the absence of data in the statistical reports of the MIAC in some regions (Table 2). If we compare the obtained data with the total number of injured per year, then we can conclude that most patients in specialized departments were treated conservatively. There was a significant fivefold decrease in the "ratio of the persons who were treated surgically to patients discharged", which might be caused by incorrect statistical reporting. At the same time, in a number of normative documents of the Ministry of Health of Russia this profile of medical care is called "surgery (combustiology)". 
The burns department of the Kurgan region operates with a stable overload, with a high rate of provision of beds per 10,000 population (Table 3). An insufficient index of "bed capacity" was registered in the burns departments of the Sverdlovsk region with a low indicator of bed availability. In the Khanty-Mansiysk Autonomous Okrug (KhMAO), this index has grown by $12 \%$ since 2014 with a high rate of bed availability.

We believe that these collisions have been also associated with the lack of a coordinated statistical reporting system.

The long-term consequences of burn injuries have an enormous physical, mental and social impact on the injured and their families [5-7]. Rehabilitation of patients with the consequences of burns continues to be one of the most difficult problems in reconstructive and plastic surgery $[8,9]$. Cicatricial deformities and contractures are inevitable due to the severity of the primary lesion and the lack of a systematic tactical approach to recovery operations. Patients with burns

contractures account for $36.5 \%$ of all patients who underwent reconstructive surgery [10]. According to the literature, reconstructive operations are a need for every second patient with the consequences of burns [11]. In our opinion, about $40 \%$ of patients who suffered a deep burn injury will need reconstructive and restorative plastic operations in the future. The proportion of patients with skin cancer, developed due to scars, accounts for 1.5-6.0 \% of the total number of patients with skin cancer [12, 13]. Skin cancer developed on post-burn scars is extremely aggressive. The rate of its metastasis and recurrence is higher if compared with skin cancer originating from non-scar tissue.

Here are several photographs of our patients who suffered thermal trauma and received reconstructive surgery on the affected segments (Fig. 4, 5, 6). The localization and area of scars in patients varies and requires an individual approach, taking into account the needs of patients to improve the quality of life.

Table 2

Number of interventions for wounds and burns performed at the thermal trauma centres in the Ural Federal District

\begin{tabular}{|l|c|c|c|c|c|}
\hline \multirow{2}{*}{ Regions } & \multicolumn{5}{c|}{ Number of interventions } \\
\cline { 2 - 6 } & 2014 & 2015 & 2016 & 2017 & 2018 \\
\hline Kurgan region & - & - & - & - & - \\
\hline Sverdlovsk region & 404 & 389 & 391 & - & - \\
\hline Tyumen region & 390 & 454 & 451 & - & - \\
\hline Chelabinsk region & 693 & 474 & 668 & - & - \\
\hline Khanty-Mansiysk Autonomous Okrug - Ugra & 369 & 227 & 245 & 330 & 285 \\
\hline Yamalo-Nenets Autonomous Okrug & - & - & - & - & - \\
\hline Total & 1856 & 1544 & 1755 & 330 & 285 \\
\hline Ratio of patients operated on to discharged ones & $25 \%$ & $22 \%$ & $26 \%$ & $5 \%$ & $5 \%$ \\
\hline
\end{tabular}

Bed capacity work at centres and departments for management of burns

Table 3

\begin{tabular}{|c|c|c|c|c|c|c|}
\hline \multirow{2}{*}{\multicolumn{2}{|c|}{ Region }} & \multicolumn{5}{|c|}{ Bed capacity work } \\
\hline & & 2014 & 2015 & 2016 & 2017 & 2018 \\
\hline \multicolumn{2}{|l|}{ Kurgan region } & 362.9 & 336.1 & 340.7 & 350.0 & 348.0 \\
\hline \multirow{2}{*}{ Sverdlovsk region } & adults & 262 & 258 & 137 & 279.9 & 273,3 \\
\hline & children & 238 & 250 & 280 & & \\
\hline \multicolumn{2}{|l|}{ Tyumen region } & 318.5 & 324.9 & 336.2 & 339 & 327 \\
\hline \multicolumn{2}{|c|}{ Chelabinsk region } & 330 & 302 & 328 & 308 & 339 \\
\hline \multicolumn{2}{|c|}{ Khanty-Mansiysk Autonomous Okrug - Ugra } & 288.1 & 273.7 & 331.0 & 334.3 & 321.8 \\
\hline \multicolumn{2}{|c|}{ Yamalo-Nenets Autonomous Okrug } & - & - & - & 279.9 & 273.3 \\
\hline
\end{tabular}

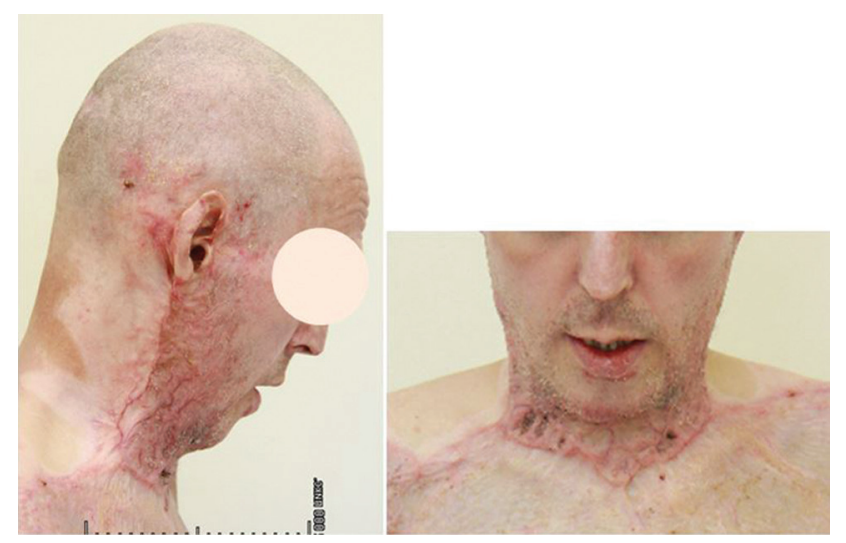

Fig. 4 Photo of a 45-year-old patient. Diagnosis: postburn contracture of the neck, impaired neck movements, impaired swallowing and breathing 

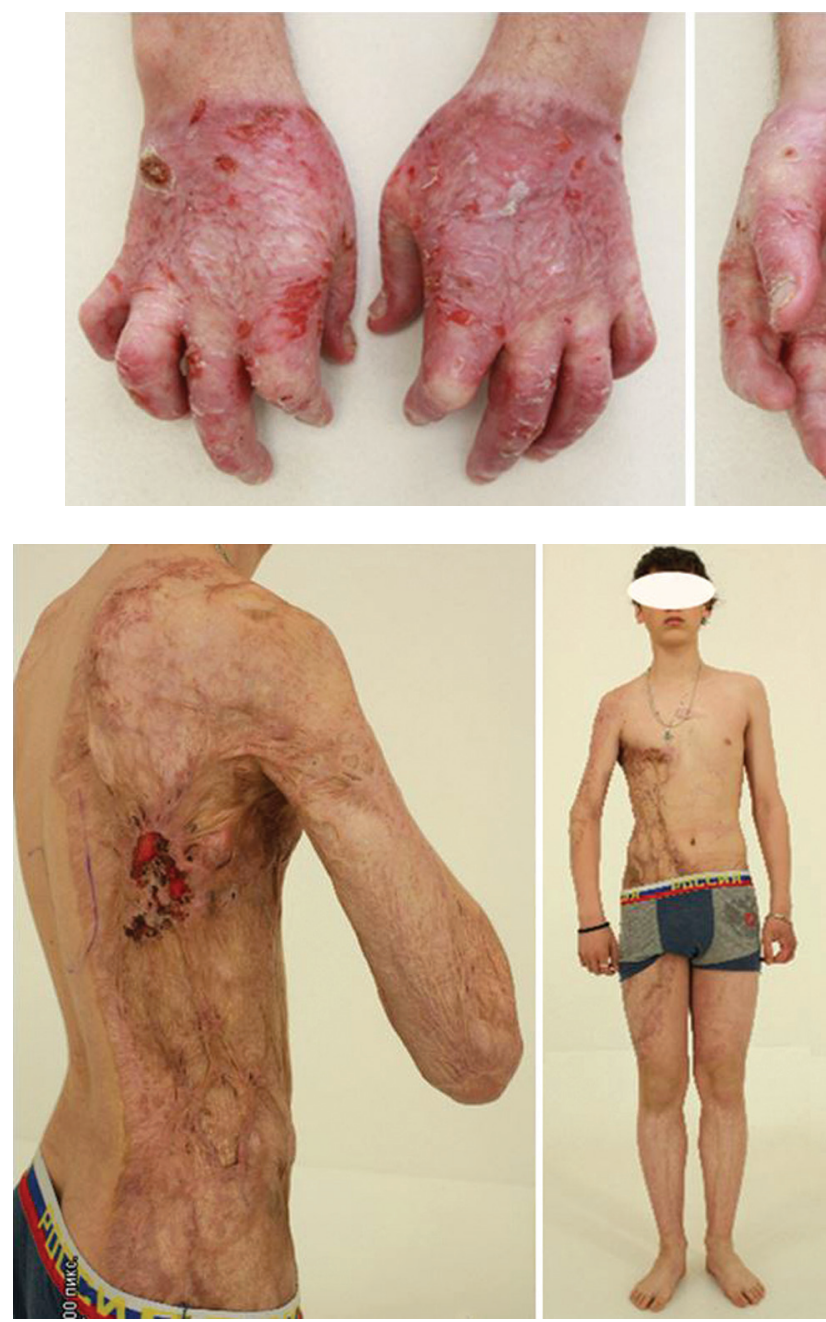

Fig. 6 Photo of a 16-year-old patient. Diagnosis: extensive scars of the right half of the body. long-term non-healing sluggishly granulating wounds in the area of scars

What actually happens to post-burn surgical rehabilitation of the injured? We asked to answer this question in the reports supplied by the regions. Information on this issue was not provided by most regions of the Ural Federal District. There is information on reconstructive operations in patients with post-burn scars and deformities in the Chelyabinsk region, Sverdlovsk region and KhantyMansiysk Autonomous Okrug in 2014; in 2018 the information on operations was presented only in the KhMAO report. It means that either no reconstructive surgeries were performed, or they were not counted.

However, patients with long-term non-healing trophic ulcers, patients who received various wounds by mechanical means, and patients with benign skin diseases occupy the "post-burn" beds. On the one hand, in fact, these are non-core patients for burn departments, but on the other hand, it is burns injury specialists (Rus. term "combustiologists") who currently have the skills to successfully treat soft-tissue and skin pathology. Major reconstructive
Fig. 5 Photo of the hands of a 54-year-old patient. Diagnosis: postburn deformities and contractures of the joints of both hands

interventions require professional competence and certification in plastic surgery, and not just advanced training in reconstructive surgery. According to the Procedure for the provision of medical care to the population in the field of "plastic surgery", approved by order of the Ministry of Health of the Russian Federation dated 05/31/2018 N 298, reconstructive and restorative operations in patients with the consequences of burns are within the competence of plastic surgeons. It is confirmed by the successful work of "burn" departments in the leading surgical centres in the European part of the Russian Federation (Vishnevsky National Medical Research Centre of Surgery, Privolzhsky Research Medical University) where doctors specializing in plastic surgery practice. In the Ural Federal District, there are no such specialists in thermal trauma departments.

In this regard, it is advisable to refer patients with the consequences of thermal injury to a specialized federal institution that meets modern requirements for the provision of specialized and high-tech care to patients with the consequences of burn injury. Organizationally and economically justified route in the Ural Federal District may be the referral of patients of this nosological group to the clinic of reconstructive plastic surgery and hand surgery of the Federal State Budgetary Institution Ilizarov National Medical Research Centre for Traumatology and Orthopaedics the RF Ministry of Health which has not only the necessary material and technical support, staffed with specialists practicing plastic surgery, experienced in the management of burns but also has a long-year experience in the treatment of various post-traumatic deformities and defects.

The most important element of planning specialized care for patients with thermal trauma and its consequences should be a unified register of patients with burns and its updating both within the framework of the specialized medical association and institutions for management of thermal trauma. 


\section{CONCLUSION}

Despite the social significance of thermal injury and the high relevance of rehabilitation of patients with acute burn injury and with post-burn scars and deformities in the long-term period [12, 14-16], the specialty "combustiology" remains one of the few medical specialties in Russia for which the Order of the procedure of rendering assistance has not been adopted.

In the regions of the Ural Federal District, there are no referral schemes for patients with burn injuries. The capacity of the existing specialized beds in the regions is uneven; most of the thermal trauma patients in specialized departments are treated conservatively. Not a single "burns" department of the Ural Federal District has a certified plastic surgeon.

It is necessary to introduce a unified approach to statistical reporting. It is feasible to deploy surgical beds at "burns" departments to provide specialized medical care to patients with various wound defects requiring autodermoplasty. The issues of referring patients with the consequences of thermal injury to a specialized federal institution and the creation of a unified register of "burn injury" patients require organizational solutions.

\section{REFERENCES}

1. Jeschke M.G., Van Baar M.E., Choudhry M.A., Chung K.K., Gibran N.S., Logsetty S. Burn injury. Nat. Rev. Dis. Primers, 2020, vol. 6, no. 1, pp. 11. DOI: 10.1038/s41572-020-0145-5.

2. World Health Organization. Burns. WHO. Available at: https://www.who.int/en/news- room/fact- sheets/detail/burns (WHO, 2018).

3. Queiroz LF., Anami E.H., Zampar E.F., Tanita M.T., Cardoso L.T., Grion C.M. Epidemiology and outcome analysis of burn patients admitted to an Intensive Care Unit in a University Hospital. Burns, 2016, vol. 42, no. 3, pp. 655-662. DOI: 10.1016/j.burns.2015.08.002.

4. Eskin N.A., editor. Travmatizm, ortopedicheskaia zabolevaemost i sostoianie travmatologo-ortopedicheskoi pomoshchi naseleniiu Rossii v 2018 godu [Traumatism, orthopaedic morbidity and the state of traumatologic-and-orthopaedic care for the population of Russia in 2018]. M. 2019, 165 p. (in Russian)

5. Logsetty S., Shamlou A., Gawaziuk J.P., March J., Doupe M., Chateau D., Hoppensack M., Khan S., Medved M., Leslie W.D., Enns M.W., Stein M.B., Asmundson G.J.G., Sareen J. Mental health outcomes of burn: A longitudinal population-based study of adults hospitalized for burns. Burns, 2016, vol. 42, no. 4, pp. 738-744. DOI: 10.1016/j.burns.2016.03.006.

6. Mason S.A., Nathens A.B., Byrne J.P., Diong C., Fowler R.A., Karanicolas P.J., Moineddin R., Jeschke M.G. Increased Rate of Long-term Mortality Among Burn Survivors: A Population-based Matched Cohort Study. Ann Surg., 2019, vol. 269, no. 6, pp. 11921199. DOI: 10.1097/SLA.0000000000002722.

7. Stone J., Gawaziuk J.P., Khan S., Chateau D., Bolton J.M., Sareen J., Enns J., Doupe M., Brownell M., Logsetty S. Outcomes in adult survivors of childhood burn injuries as compared with matched controls. J. Burn Care Res., 2016, vol. 37, no. 2, pp. e166-e173. DOI: 10.1097/BCR.0000000000000323.

8. Afonichev K.A, Filippova O.V. Analiz oslozhnennykh iskhodov ozhogov u detei [Analysis of the complicated outcomes of burns in children]. Ortopediia, Travmatologiia i Vosstanovitelnaia Khirurgiia Detskogo Vozrasta, 2015, vol. 3, no. 3, pp. 21-25. (in Russian)

9. Filippova O.V., Afonichev K.A., Baindurashvili A.G., Goliana S.I., Stepanova Iu.V., Tsyplakova M.S. Osobennosti razvitiia vtorichnykh deformatsii u detei s rubtsovymi posledstviiami ozhogov, printsipy khirurgicheskogo lecheniia [Characteristic features of secondary deformity development in children with scarring consequences of burns, principles of surgical treatment]. Travmatologiia i Ortopediia Rossii, 2012, no. 1, pp. 77-84. (in Russian)

10.Sarygin P.V., Korotkova N.L. Razrabotka unifitsirovannogo podkhoda k khirurgicheskomu lecheniiu rubtsovykh porazhenii nizhnei treti litsa posle ozhoga [Development of a unified approach to surgical treatment of scar lesions of face lower third after a burn]. Annaly Khirurgii, 2012, no. 6, pp. 10-14. (in Russian)

11.Cartotto R., Cicuto B.J., Kiwanuka H.N., Bueno E.M., Pomahac B. Common postburn deformities and their management. Surg. Clin. North Am., 2014, vol. 94, no. 4, pp. 817-837. DOI: 10.1016/j.suc.2014.05.006.

12.Dmitriev G.I., Arefev I.Iu., Korotkova N.L., Menshenina E.G., Poiato T.V., Bogosian R.A., Poliakova A.G. Sovershenstvovanie kompleksnoi reabilitatsii bolnykh s posledstviiami ozhogov [Improving the complex rehabilitation of patients with burn consequences]. Meditsinskii Almanakh, 2010, no. 2, pp. 225-228. (in Russian)

13.Gantsev Sh.Kh., Iusupov A.S. Ploskokletochnyi rak kozhi [Squamous cell cancer of the skin]. Prakticheskaia Onkologiia, 2012 , vol. 13, no. 2, pp. 80-91. (in Russian)

14.Sokolov V,A,, Efimenko N.A., Admakin A.L., Petrachkov S.A., Stepanenko A.A. Ozhogi mirnogo vremeni. Istochniki opasnosti [Peacetime burns. Sources of danger]. Klinicheskaia Meditsina, 2015, no. 6, pp. 30-35. (in Russian)

15. Tiurnikov Iu.I. Sovremennye aspekty okazaniia i lechebno-diagnosticheskoi pomoshchi pri termicheskoi travme [Modern aspects of providing and medical-diagnostic care for thermal injury]. Plasticheskaia Khirurgiia i Kosmetologiia, 2012, no. 2, pp. 257-266. (in Russian)

16.Unizhaeva A.Iu., Martynchik S.A. Mediko-ekonomicheskaia otsenka zatrat i kachestva statsionarnoi travmy pri ozhogovoi travme [Medical-and-economic assessment of the costs and quality of stationary trauma in burn injury]. Sotsialnye Aspekty Zdorovia Naseleniia, 2012, no. 6, pp. 28. (in Russian)

Received: 12.03 .2020

\section{Information about the authors:}

1. Mikhail Yu. Korostelev, M.D.,

Ilizarov National Medical Research Centre for Traumatology and Orthopedics, Kurgan, Russian Federation, Email: 2351724@mail.ru

2. Natalia G. Shikhaleva, M.D., Ph.D.,

Ilizarov National Medical Research Centre for Traumatology and Orthopedics, Kurgan, Russian Federation,

Email: nshihaleva@mail.ru

3. Alexander V. Gubin, M.D., Ph.D.,

National Medical Research Center of Traumatology and Orthopedics n.a. N.N. Priorov, Moscow, Russian Federation, Email: shugu19@gubin.spb.ru
4. Sergey O. Ryabykh, M.D., Ph.D.,

Ilizarov National Medical Research Centre for Traumatology and Orthopedics, Kurgan, Russian Federation, Email: rso_@mail.ru

5. Olga B. Borzunova,

Ilizarov National Medical Research Centre for Traumatology and Orthopedics, Kurgan, Russian Federation, Email: olbor99@mail.ru 